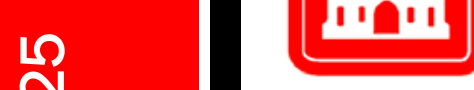

US Army Corps

of Engineers ${ }_{\circledast}$

Engineer Research and

Development Center

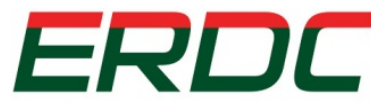

INNOVATIVE SOLUTIONS for a safer, better world

Army Environmental Quality Technology

\title{
An Evaluation of Methods for Assessing Vulnerability of Army Installations to Impacts of Climate Change on Listed and At-Risk Species
}

Matthew G. Hohmann, David K. Delaney, and

July 2017

Michelle E. Swearingen
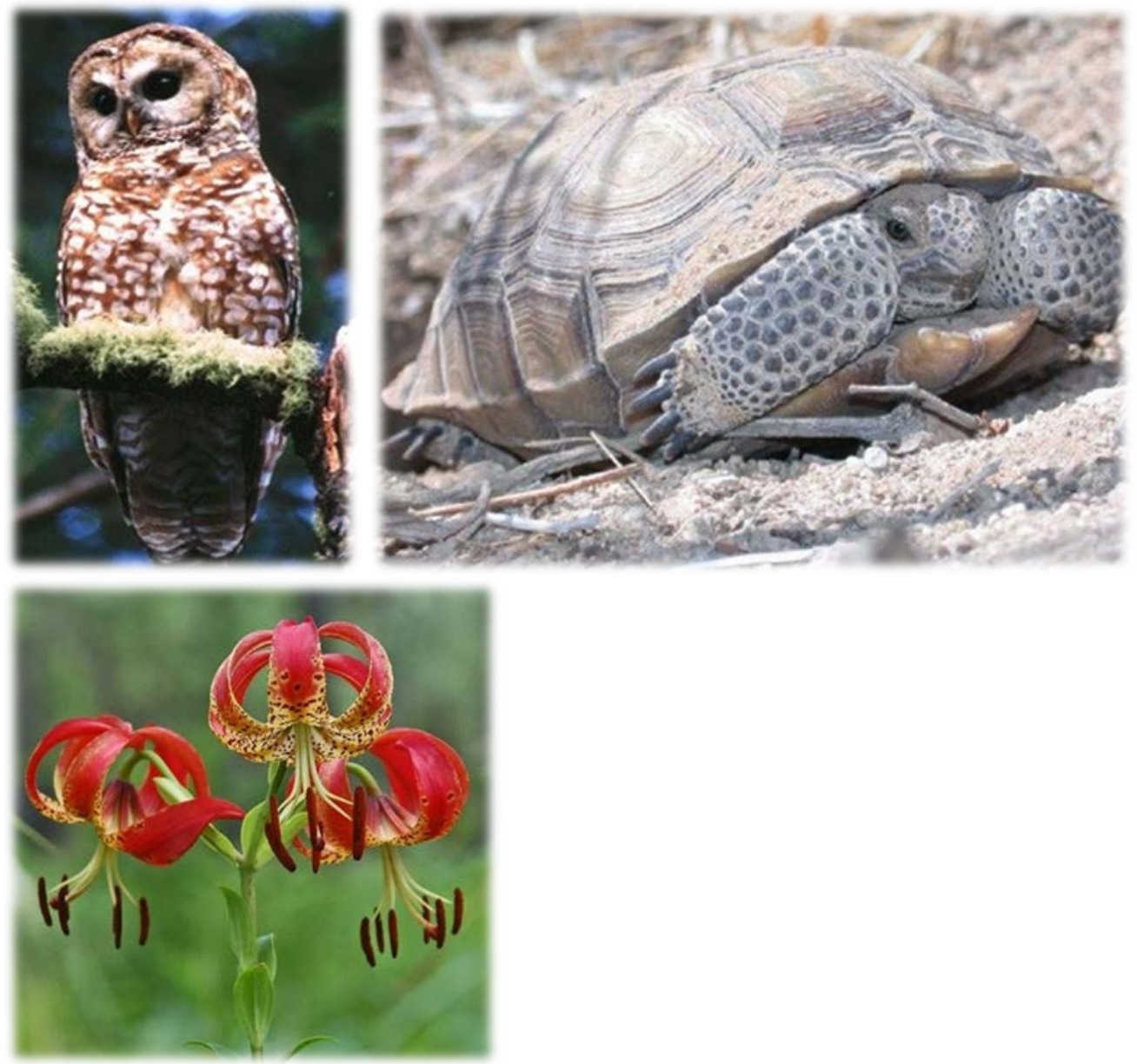
The US Army Engineer Research and Development Center (ERDC) solves the nation's toughest engineering and environmental challenges. ERDC develops innovative solutions in civil and military engineering, geospatial sciences, water resources, and environmental sciences for the Army, the Department of Defense, civilian agencies, and our nation's public good. Find out more at www.erdc.usace.army.mil.

To search for other technical reports published by ERDC, visit the ERDC online library at http:// acwc.sdp.sirsi.net/ client/ default. 


\section{An Evaluation of Methods for Assessing Vulnerability of Army Installations to Impacts of Climate Change on Listed and At-Risk Species}

Matthew G. Hohmann, David K. Delaney, and Michelle E. Swearingen

Construction Engineering Research Laboratory

U.S. Army Engineer Research and Development Center

2902 Newmark Drive

Champaign, IL 61822

Final report

Approved for public release; distribution is unlimited.

Prepared for Office of Assistant Secretary of the Army for Acquisition, Logistics, and Technology

1400 Defense Pentagon

Washington DC 20301-1400

Under Project 2DC5L9, "Firing Range Capacity" 


\section{Abstract}

Environmental factors have received only limited attention as part of past Base Realignment and Closure (BRAC) decision-making processes, and climate-change impacts have not yet been considered. During BRAC 2005, the Army considered listed and at-risk species as part of its environmental-criterion analysis. These species affect BRAC analyses given that their status can lead to restrictions on training land use, and that such restrictions are likely to increase under future rules addressing climate change. The objectives of this work were to identify prospective approaches for assessing the vulnerability of installations to climate-change impacts on listed and at-risk species, and to evaluate their suitability for informing BRAC-related evaluations. Three recently developed methods for assessing the vulnerability of Army installations to impacts of climate change on listed and at-risk species were evaluated using the SMART (Specific, Measurable, Attainable, Realistic, and Timely) decision analysis framework. Each method was rated against the SMART criteria and an aggregate score was provided. The assessment approach having the maximum aggregate score was recommended as likely suitable for informing future BRAC and restationing evaluations. It characterizes installation and regional climate change vulnerability by integrating multiple factors related to exposure, sensitivity, adaptive capacity, and number of listed and at-risk species.

DISCLAIMER: The contents of this report are not to be used for advertising, publication, or promotional purposes. Citation of trade names does not constitute an official endorsement or approval of the use of such commercial products. All product names and trademarks cited are the property of their respective owners. The findings of this report are not to be construed as an official Department of the Army position unless so designated by other authorized documents. 


\section{Contents}

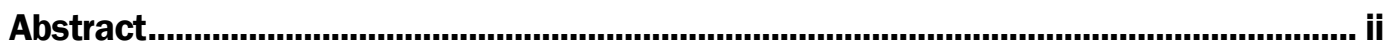

Preface ................................................................................................................................iv

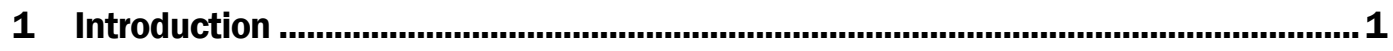

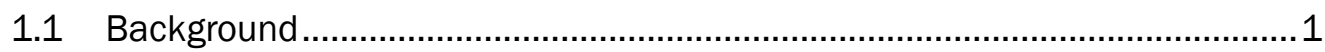

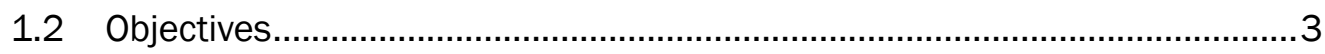

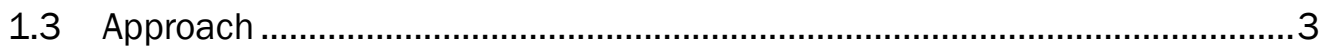

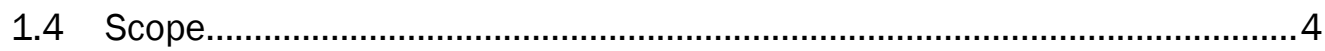

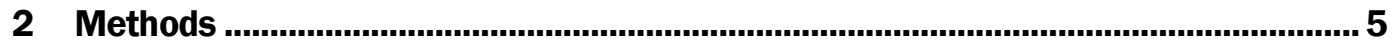

2.1 At-risk and listed species density rankings (Wilhoit et al. 2016)...................5

2.2 Multiscale assessment of climate change vulnerability (Hohmann

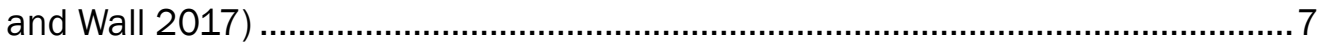

2.3 Climate change attributable to listed and at-risk species (Hohmann, Delaney, and Wall 2017) .................................................................................

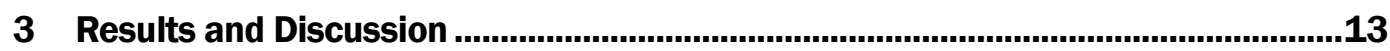

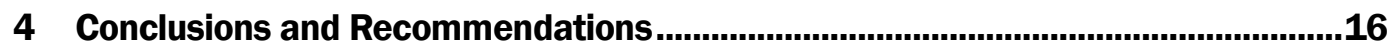

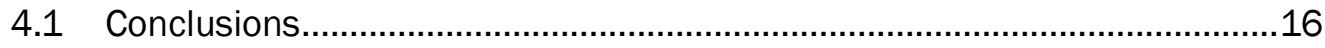

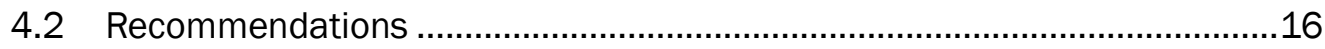

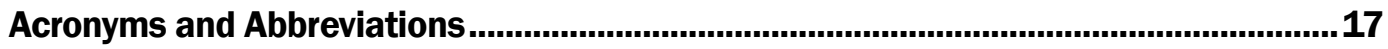

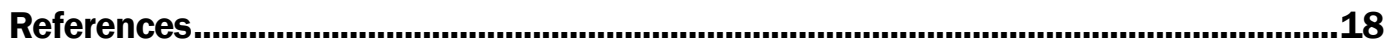

Report Documentation Page 


\section{Preface}

This study was conducted for Office of the Assistant Secretary of the Army for Acquisition, Logistics, and Technology, ASA(ALT) under Research, Development, Test and Evaluate (RDTE) Program Element 622720A896, "Army Environmental Quality Technology"; Project 2DC5L9, "Firing Range Capacity." The technical monitor was Alan B. Anderson, CEERDCZT.

This work was conducted by the Ecological Processes Branch of the Installations Division (CEERD-CNN), Construction Engineering Research Laboratory, Engineer Research and Development Center (ERDC-CERL). The At the time of publication, Dr. Chris Rewerts was Chief, CEERD-CNN; Michelle J . Hanson was Chief, CEERD-CN; and Alan B. Anderson, CEERD-CZT, was the Technical Director for Sustainable Ranges and Lands. The Deputy Director of ERDC-CERL was Dr. Kirankumar Topudurti and the Director was Dr. Ilker Adiguzel.

The Commander of ERDC was COL Bryan S. Green and the Director was Dr. David W. Pittman. 


\section{Introduction}

\subsection{Background}

The Department of Defense (DoD) manages over 25 million acres of land across 425 major military installations and is the third largest federal land-managing agency in the United States. DoD lands host the highest density of federally listed species under the Endangered Species Act (ESA) - more than any other federal land-management agency (NatureServe 2011). Nearly half of total DoD acreage is managed by the Department of the Army (DA) and encompasses more than 120 major installations. Army installations contain more than twice the number of threatened and endangered species (TES) and at-risk species than land managed by the other military departments (NatureServe 2011; Stein et al. 2008). DoD lands are managed primarily for military training and testing activities in support of combat readiness, which represents a much different land-use regime than applied to other federal lands. Natural resource programs on DoD installations support the military mission by ensuring access to realistic training lands while providing for the long-term sustainability of natural resources. Climate change is anticipated to increase the management complexity and workload for installations, and negatively impact their ability to manage listed and at-risk species. Such a situation increases the likelihood that the presence of species will drive additional restrictions on military access to training lands (DoD 2014).

Another round of BRAC determinations, if any, is not expected before 2021 (Defense News 2016). Environmental factors have received limited consideration in the past as part of the BRAC Selection Criterion 8 analysis (U.S. Government Accountability Office 2005). Besides Criterion 8, the Army also considered noise contours, soil resiliency, water quantity, and air quality as environmental factors in their Military Value Analysis (MVA). Previous BRAC determinations also have considered environmental impacts, such as cost of potential environmental restoration, waste management, and environmental compliance (BRAC 2005). However, climate change impacts have not been addressed to date. DoD concerns about potential climate change impacts on military capability include effects on plans and operations, training and testing, built and natural infrastructure, and acquisition/ supply chain (DoD 2014). A recent report by the 
CNA Military Advisory Board recommended that climate change be included in future BRAC considerations (CNA 2014).

The Army needs a means of identifying the impact of future climate change on installations in order to inform long-term sustainability decisions. Such data are needed to support diverse areas of decision making such as training mission assignments, BRAC military value attributes and installation rankings, conservation funding investments, and alternative mitigation strategy selection. Climate-change vulnerability assessments have been applied across various land management agencies to identify current and future climate-change priorities on different assessed factors of interest. Climate change vulnerability assessments are coarse-filter approaches for developing qualitative categorization of vulnerability and sensitivity factors. A number of different approaches have been developed to assess the vulnerability and sensitivity of wildlife species to climate change on federal (e.g., Bagne et al. 2011), state (e.g., Gardali et al. 2012), and tribal lands (e.g., Mawdsley and Lamb 2013). The most widely used and available assessment tool is the NatureServe Climate Change Vulnerability Index, or NS CCVI (Young et al. 2015).

Three different approaches for assessing climate change vulnerability of Army installations in relation to listed and at-risk species have recently been developed. Wilhoit et al. (2016) proposed a simple method of ranking installations based on the potential impacts of climate change, as related to listed and at-risk species management, on training-land use. However, their approach did not include any specific information about climate change vulnerability, but was instead based on the number of species on installations, the conservation status of these species (i.e., federally listed, proposed for listing, and at risk), listing probabilities of different taxonomic groups, and installation area. Effectively, this ranking metric calculates a status and probability of listing-adjusted estimate of at-risk and listed species density.

Hohmann and Wall (2017) developed and demonstrated an approach to multiscale climate change vulnerability assessment that evaluates exposure, sensitivity, and adaptive capacity while integrating weighted estimates of listed and at-risk species range-wide and local vulnerability. It explicitly acknowledges that the magnitude of the added challenge posed by climate change to species management will be determined not only by 
vulnerability within the portions of species' ranges encompassed by installations, but also by their range-wide or regional vulnerability. In other words, the prospects for species recovery and the strategies available to achieve that recovery are a combination of both local and range-wide factors. For example, climate-change-driven loss of habitat in a large portion of a sensitive species range will likely constrain certain adaptation strategies and demand others. Moreover, their approach specifically assesses vulnerability on Federal land within species ranges as the status of these protected occurrences often influences ESA listing decisions. To date, there is a trend among public land managers to use single scale climate change vulnerability assessments. These assessments focus primarily on single facilities, regions, or jurisdictional boundaries that individually may not have inherent biological meaning for species conservation (e.g., Byers and Norris 2011) and therefore offer limited insight about vulnerability and what adaptation strategies might be most appropriate.

Applying a more simplified approach than Hohmann and Wall (2017) but more sophisticated than Wilhoit et al. (2016), Hohmann, Delaney, and Wall (2017) developed an approach for characterizing installation climate change vulnerability that integrates multiple factors related to exposure, sensitivity, adaptive capacity, and number of listed and at-risk species. Their approach not only evaluates these factors for focal installations but also within the surrounding landscape, the latter being expected to influence the success of local conservation goals.

\subsection{Objectives}

The objectives of this work were to (1) identify a candidate approach for assessing the vulnerability of Army installations to impacts that climate change may have on listed and at-risk species and (2) evaluate its suitability for informing future BRAC and restationing evaluations.

\subsection{Approach}

Three recently developed methods for assessing vulnerability of Army installations to impacts of climate change on listed and at-risk species were evaluated using the SMART (Specific, Measurable, Attainable, Realistic, and Timely) management framework. Each of the three methods was rated on each criterion and an aggregate score was provided identifying which of the three approaches best fit with the SMART framework. The approach having the maximum aggregate score is recommended as the one most 
likely to be suitable for informing future BRAC and other strategic stationing studies.

\subsection{Scope}

The scope of this study was limited to continental United States (CONUS) installations and species that have either been federally listed as threatened or endangered, or that have been identified to be at risk (NatureServe 2014). 


\section{Methods}

We evaluated the three approaches for suitability as an attribute within the Center for Army's Analysis (CAA) Military Value Analysis (MVA) models and decision methods for Army stationing decisions. The CAA utilizes the SMART management framework to determine if an attribute meets a minimum standard for inclusion within the MVA model. If an attribute meets the SMART threshold, it may be included in MVA depending on its importance. Descriptions of the five SMART criteria are listed in Table 1.

Table 1. SMART goal definitions.

\begin{tabular}{|l|l|}
\hline Attribute & Definition \\
\hline Specific & $\begin{array}{l}\text { The goal is clear and focused to avoid misinterpretation; assumptions } \\
\text { and definitions can be easily interpreted or explained. }\end{array}$ \\
\hline Measurable & $\begin{array}{l}\text { The goal be quantified and compared to other data; should allow for } \\
\text { meaningful statistical analysis (avoid binary "yes/no" measures - those } \\
\text { become "screening" criteria). }\end{array}$ \\
\hline Attainable & $\begin{array}{l}\text { The goal is achievable, reasonable, and credible under conditions } \\
\text { expected. }\end{array}$ \\
\hline Realistic & The goal fits into the model and maintains cost-effectiveness. \\
\hline Timely & The goal is achievable within the time frame given. \\
\hline
\end{tabular}

We applied this framework in our evaluation and used a simple five-point scoring system ( 5 = best, 1 =worst) based on subject-matter expert assessment of how well each approach meets the five SMART criteria. We also considered whether climate-change-related vulnerabilities attributable to listed and at-risk species should be used as a supplemental criterion outside the model (e.g., within the existing environmental and socioeconomic impacts criterion). Additional details for each of the three climate-change vulnerability approaches are provided below to consolidate information relevant for our evaluation.

\subsection{At-risk and listed species density rankings (Wilhoit et al. 2016)}

A spreadsheet of listed and at-risk species from seven regionally distinct Army installations of interest was compiled based on information from environmental and installation documents (e.g., Integrated Natural Resources Management Plans [INRMP], Environmental Assessments, Environmental Impact Statements, etc.) (Wilhoit et al. 2016, Appendix D). Species were weighted with a multiplier based on their status under ESA. All federally listed species (e.g., endangered or threatened) or candidate species received a weight of 1 . At-risk species were multiplied by 0.25 as an 
approximation of the uncertainty in future listing given they have not yet been petitioned for listing under the ESA. At-risk species and species under ESA review also received probability of ESA listing weights derived from Sperry, Wall, and Hohmann (2016) according to taxonomic group, which ranged from 0.29 for arthropods to 1.0 for turtles. All the derived values were then summed and added to the number of listed species on each of seven regional case study installations. Because the magnitude of impact of listed and at-risk on training was expected to vary as a function of available training area, these totals were then divided by installation area $\left(\mathrm{km}^{2}\right)$ to generate a single non-normalized impact (i.e., vulnerability) score for each installation (Wilhoit et al. 2016). The vulnerability scores generated by Wilhoit et al. (2016) for case-study installations ranged from 1.51 to 0.00 , but most impact scores were either 0 or 0.01 (Table 2). Still, installations with higher impact scores had greater numbers of listed and at-risk species and smaller land areas than installations that were estimated to have the lowest score, which had fewer listed and at-risk species and larger land areas (Wilhoit et al. 2016).

This approach offers a simple method for ranking installations based on potential impacts of climate change on listed and at-risk species relative to training land use (Wilhoit et al. 2016). It does not include any specific information about climate-change vulnerability nor does it account for the importance of differences in scores. The purpose of this method was to develop a rapid, easy process for assessing the vulnerability of Army installations to impacts of climate change on listed and at-risk species, which could potentially be used to guide the decision matrix for future BRAC and restationing evaluations.

Table 2. Climate change vulnerability scores and (rankings) of five CONUS installations evaluated by the three approaches. Higher scores equate to greater vulnerability, while higher ranks equate to lower vulnerability.

\begin{tabular}{|l|l|l|l|l|}
\hline Installation & Location & $\begin{array}{l}\text { Wilhoit et al. } \\
\mathbf{( 2 0 1 6 )}\end{array}$ & $\begin{array}{l}\text { Hohmann and } \\
\text { Wall (2017) }\end{array}$ & $\begin{array}{l}\text { Hohmann, } \\
\text { Delaney and } \\
\text { Wall (2017) }\end{array}$ \\
\hline $\begin{array}{l}\text { Joint Base Lewis- } \\
\text { McChord }\end{array}$ & Washington & $0.01(1)$ & $6.69(1)$ & $1.103(1)$ \\
\hline Fort Bragg & North Carolina & $0.01(1)$ & $2.37(2)$ & $0.783(3)$ \\
\hline Fort Bliss & Texas & $0.0(2)$ & $1.39(3)$ & $0.901(2)$ \\
\hline Fort Drum & New York & $0.0(2)$ & $0.02(4)$ & $0.592(5)$ \\
\hline Fort Riley & Kansas & $0.01(1)$ & $0.02(4)$ & $0.776(4)$ \\
\hline
\end{tabular}




\subsection{Multiscale assessment of climate change vulnerability (Hohmann and Wall 2017)}

Hohmann and Wall (2017) used NS CCVI version 3.0, with several small modifications explained in the report, to assess local and range-wide vulnerabilities for species on the five CONUS installations evaluated by Wilhoit et al. (2016). The NS CCVI index places species into one of five vulnerability categories - extremely vulnerable, highly vulnerable, moderately vulnerable, less vulnerable, and insufficient evidence-for a specific geographical area assessed, through 2050 (Young et al. 2015). It uses information about 23 factors to characterize species sensitivity, exposure, and capacity to adapt to climate change. Examples of these factors include exposure to sea-level change, phenological response to changing seasonal temperature or precipitation, and dispersal and movement capability. Table 3 lists and briefly describes these factors. Additional details and scoring guidelines for the factors can be found in Young et al. (2015).

The NS CCVI can be used to (1) assess species' relative vulnerability, (2) to identify the most important factors affecting vulnerability, (3) identify conservation priorities across specific areas (e.g., jurisdictional boundaries or physiographic regions), and (4) to promote coordination and consistency in adaptation planning and management (Young et al. 2015). However, application of the index is somewhat constrained in regions outside the conterminous United States due to availability of consistent climate data and certain design features. The tool, which is programmed into a Microsoft Excel ${ }^{*}$ workbook, is freely available for download at www.natureserve.org/ccvi.

By applying the NS CCVI across entire species ranges and specifically to the portions of their ranges represented by installations and other federal lands, and then comparing values across species and locations, Hohmann and Wall (2017) sought to (1) identify the relative threat that climate change likely poses for the future conservation of various species found on the case study installations, (2) assess the challenges that climate change likely poses for the installations' ability to positively affect species' conservation, and (3) identify the conservation partnering and adaptation strategies likely available.

\footnotetext{
* Microsoft and Excel are registered trademarks of Microsoft Corp., Redmond, WA.
} 
Table 3. Factors assessed by the NS CCVI tool (Young et al. 2015).

\begin{tabular}{|c|c|c|}
\hline Aspect of Vulnerability* & Factor & Description \\
\hline \multirow[t]{2}{*}{ A. Direct Exposure } & A1. Temperature Change & $\begin{array}{l}\text { Predicted change in annual temperature by } 2050 \text {, calculated } \\
\text { over the range of the species and for Federal lands. }\end{array}$ \\
\hline & A2. Moisture Change & $\begin{array}{l}\text { Predicted net change in moisture based on the Hamon actual } \\
\text { evapotranspiration (AET) potential evapotranspiration (PET) } \\
\text { Moisture Metric, calculated over the range of the species and } \\
\text { for Federal lands. }\end{array}$ \\
\hline \multirow[t]{4}{*}{ B. Indirect Exposure } & B1. Sea-Level Rise & $\begin{array}{l}\text { Predicted increase in sea level and consequent influence of } \\
\text { storm surges calculated over the range of the species and for } \\
\text { Federal lands. }\end{array}$ \\
\hline & B2A. Natural Barriers & $\begin{array}{l}\text { Topographic, geographical, and/or ecological features of the } \\
\text { landscape that may naturally restrict a species from } \\
\text { dispersing to new areas. }\end{array}$ \\
\hline & B2B. Anthropogenic Barriers & $\begin{array}{l}\text { Anthropogenically altered landscapes (e.g., urban or } \\
\text { agricultural areas) that may hinder the dispersal of a species. }\end{array}$ \\
\hline & $\begin{array}{l}\text { B3. Land Use Changes from } \\
\text { Climate Change Mitigation }\end{array}$ & $\begin{array}{l}\text { Strategies designed to mitigate greenhouse gases (e.g., large } \\
\text { wind farms, biofuel production, solar arrays, carbon offsets), } \\
\text { or other threats. }\end{array}$ \\
\hline \multirow[t]{9}{*}{$\begin{array}{l}\text { C. Sensitivity and Adaptive } \\
\text { Capacity }\end{array}$} & C1. Dispersal/ Movement & $\begin{array}{l}\text { Known or predicted dispersal or movement capability of } \\
\text { species and ability to shift location as conditions change due } \\
\text { to climate change. Limited dispersal or movement capability is } \\
\text { expected to increase vulnerability. }\end{array}$ \\
\hline & C2ai. Historical Thermal Niche & $\begin{array}{l}\text { Mean seasonal temperature variation (difference between the } \\
\text { highest mean monthly maximum temperature and lowest } \\
\text { mean monthly minimum temperature from 1951-2006) } \\
\text { calculated over the range of the species and Federal lands. } \\
\text { Species exposed to low seasonal temperature variation are } \\
\text { expected to be more vulnerable than species exposed to high } \\
\text { seasonal temperature variation. }\end{array}$ \\
\hline & $\begin{array}{l}\text { C2aii. Physiological Thermal } \\
\text { Niche }\end{array}$ & $\begin{array}{l}\text { Species' predicted sensitivity due to specific requirements for } \\
\text { relatively cool temperature regimes. }\end{array}$ \\
\hline & $\begin{array}{l}\text { C2bi. Historical Hydrological } \\
\text { Niche }\end{array}$ & $\begin{array}{l}\text { Mean annual precipitation variation (difference between the } \\
\text { maximum and minimum from 1951-2006) calculated over } \\
\text { the range of the species and for Federal lands. }\end{array}$ \\
\hline & $\begin{array}{l}\text { C2bii. Physiological } \\
\text { Hydrological Niche }\end{array}$ & $\begin{array}{l}\text { Species' predicted sensitivity due to specific requirements for } \\
\text { narrow precipitation/hydrologic regimes. }\end{array}$ \\
\hline & C2c. Disturbance & $\begin{array}{l}\text { Species' dependence on specific disturbance regimes (e.g., } \\
\text { fire or flooding likely to be impacted by climate change). } \\
\text { Dependence on specific disturbance regimes is expected to } \\
\text { increase vulnerability. }\end{array}$ \\
\hline & C2d. Ice/Snow & $\begin{array}{l}\text { Species' dependence on habitats associated with ice, ice } \\
\text { edge, or snow cover. Dependence on these habitats is } \\
\text { expected to increase vulnerability. }\end{array}$ \\
\hline & C3. Rarity of Physical Habitat & $\begin{array}{l}\text { Species' dependence on uncommon geological features or } \\
\text { derivatives (e.g., specific substrates, soils, or physical features } \\
\text { such as caves, cliffs, or sand dunes). }\end{array}$ \\
\hline & $\begin{array}{l}\text { C4a. Dependence on Other } \\
\text { Species for Habitat }\end{array}$ & $\begin{array}{l}\text { Specificity of species' dependence on habitat generated by } \\
\text { other species (e.g., burrows, cavities). }\end{array}$ \\
\hline
\end{tabular}

* Note that the factor-numbering hierarchy in this table is the same as used in the NS CVVI tool. 


\begin{tabular}{|c|c|c|}
\hline Aspect of Vulnerability* & Factor & Description \\
\hline & C4b. Diet Specialization & $\begin{array}{l}\text { Specificity of species' diets. Only applicable to animals. Dietary } \\
\text { specialists are more likely to be negatively affected by climate } \\
\text { change than species that consume diverse food types (e.g., } \\
\text { omnivores). }\end{array}$ \\
\hline & C4c. Pollinators Specialization & $\begin{array}{l}\text { Specificity of species' reliance on other species for pollination. } \\
\text { Only applicable to plants. Pollinator specialists are more likely } \\
\text { to be negatively affected by climate change than species with } \\
\text { multiple pollinators. }\end{array}$ \\
\hline & $\begin{array}{l}\text { C4d. Dependence on Other } \\
\text { Species for Dispersal }\end{array}$ & $\begin{array}{l}\text { Specificity of species' reliance on other species for propagule } \\
\text { dispersal. Applicable to both plants and animals. Dispersal } \\
\text { specialists are more likely to be negatively affected by climate } \\
\text { change than species with many dispersal agents or species } \\
\text { that are not reliant on other species for dispersal (e.g., most } \\
\text { animals). }\end{array}$ \\
\hline & $\begin{array}{l}\text { C4e. Sensitivity to Pathogens } \\
\text { or Natural Enemies }\end{array}$ & $\begin{array}{l}\text { Anticipated change in impact or abundance of pathogens and } \\
\text { natural enemies (e.g., predators, parasitoids, or herbivores) } \\
\text { due to climate change. }\end{array}$ \\
\hline & $\begin{array}{l}\text { C4f. Sensitivity to Competition } \\
\text { From Native or Non-native } \\
\text { Species }\end{array}$ & $\begin{array}{l}\text { Anticipated change in impact or abundance of native or non- } \\
\text { native competitors due to climate change. }\end{array}$ \\
\hline & $\begin{array}{l}\text { C4g. Dependence on Any } \\
\text { Other Species Interaction }\end{array}$ & $\begin{array}{l}\text { Specificity of species' reliance on other species for } \\
\text { interactions (e.g., mutualism, parasitism, commensalism or } \\
\text { predator-prey relationship) not captured by the preceding four } \\
\text { factors. }\end{array}$ \\
\hline & $\begin{array}{l}\text { C5a. Documented Genetic } \\
\text { Variation }\end{array}$ & $\begin{array}{l}\text { Relative amount of genetic variation reported for species } \\
\text { compared to findings on related taxa using similar techniques. } \\
\text { Low genetic variation is presumed to be a constraint on } \\
\text { adaptation. }\end{array}$ \\
\hline & C5b. Past Genetic Bottleneck & $\begin{array}{l}\text { Used only if genetic variation is unknown. Evidence of a past } \\
\text { genetic bottleneck suggests some potential loss of genetic } \\
\text { variation and increased vulnerability. }\end{array}$ \\
\hline & C5c. Reproductive System & $\begin{array}{l}\text { Proxy evaluated only for plants and when information about } \\
\text { species' genetic variation and past genetic bottlenecks is } \\
\text { unavailable. }\end{array}$ \\
\hline & $\begin{array}{l}\text { C6. Documented Phenological } \\
\text { Response }\end{array}$ & $\begin{array}{l}\text { Relative change in phenological variables (e.g., flowering or } \\
\text { migration times) in response to changes in climate. A lack of } \\
\text { change in phenological variables is presumed to increase } \\
\text { vulnerability. Species restricted to asexual reproduction are } \\
\text { expected to be more vulnerable than species with either } \\
\text { obligate outcrossing or mixed mating (selfing and outcrossing) } \\
\text { systems when no disruptions to gene flow (e.g., range } \\
\text { disjunctions) or outbreeding depression are known. }\end{array}$ \\
\hline \multirow[t]{4}{*}{$\begin{array}{l}\text { D. Documented or } \\
\text { Modeled Response }\end{array}$} & $\begin{array}{l}\text { D1. Documented Response to } \\
\text { Recent Climate Change }\end{array}$ & $\begin{array}{l}\text { Degree to which a species is known to have responded to } \\
\text { climate change over the past } 10 \text { years or three generations, } \\
\text { whichever is longer. }\end{array}$ \\
\hline & $\begin{array}{l}\text { D2. Modeled Future (2050) } \\
\text { Change in Range or Population } \\
\text { Size }\end{array}$ & $\begin{array}{l}\text { Predicted future change in species' range size or abundance } \\
\text { (expressed as a percentage) as a result of climate change. }\end{array}$ \\
\hline & $\begin{array}{l}\text { D3. Overlap of Modeled Future } \\
\text { Range and Current Range }\end{array}$ & $\begin{array}{l}\text { Percent of species' current range represented by the } \\
\text { intersection of predicted future (2050) and current ranges. }\end{array}$ \\
\hline & $\begin{array}{l}\text { D4. Occurrence of Protected } \\
\text { Areas in Modeled Future } \\
\text { Range }\end{array}$ & $\begin{array}{l}\text { Percent of species' predicted future (2050) range represented } \\
\text { by designated conservation areas that are likely to provide } \\
\text { conditions suitable for viable populations of the species. }\end{array}$ \\
\hline
\end{tabular}


Hohmann and Wall (2017) also generated a multiscale index of species' climate change vulnerability by combining the species' vulnerabilities estimated at the different scales (i.e., species' ranges, installations, other federal lands within species' ranges). This was accomplished by coding the categorical outputs of the NS CCVI tool at both range-wide and local scales and then combining those values with an index of relative vulnerability on federal lands across each species range. Specifically, the NS CCVI outputs were coded as follows:

- Extremely vulnerable $=1$

- Highly vulnerable $=0.75$

- Moderately vulnerable $=0.5$

- Less vulnerable $=0.25$

Weights were then applied to the vulnerabilities at these three scales to reflect their hierarchical importance for determining species' multiscale vulnerability (range-wide $=3$, Federal lands $=2$, installation $=1$ ). The products of the vulnerability values and weights at each scale were then multiplied to generate a multiscale vulnerability index. For example, the Oregon spotted frog (Rana pretiosa) was found to be highly vulnerable on J oint Base Lewis-McChord and range-wide, and extremely vulnerable across federal lands within its range, which generated the multiscale climate change vulnerability value of $3.37[(0.75 * 1) *(1 * 2) *(0.75 * 3)]$.

The values calculated for species multiscale vulnerabilities were then summed for each installation to generate an aggregated multispecies index of installation vulnerability. For example, the multiscale vulnerabilities of Spague's pipit (Anthus spragueii), western yellow-billed cuckoo (Coccyzus americanus occidentalis) and New Mexico jumping mouse (Zapus hudsonius luteus) on Fort Bliss were 0.00, 0.28, and 1.11, respectively. When summed, the aggregate vulnerability of these three species on the installation equaled 1.39. For the five installations evaluated, the aggregate multiscale index of installation vulnerability ranged from 0.02 to 6.69. It is important to note that, in developing their approach, Hohmann and Wall (2017) used species recently proposed for listing under the ESA (Sperry, Wall, and Hohmann 2016), rather than listed or at-risk species. Consequently, the values and their rankings are not directly comparable with the vulnerabilities estimated by the two other approaches (Table 2). 
The approach to multiscale vulnerability assessment developed by Hohmann and Wall (2017) is likely suitable for integrating climate-change considerations into installation Integrated Natural Resource Management Plans, evaluating whether climate-change-driven impacts to listed species will likely affect installation resilience, and strategically identifying potential conservation partners among Federal land managers. Key among their findings was the role the DoD may be expected to contribute to species' conservation in the face of climate change relative to that of other Federal land management agencies. DoD was the leading federal management agency for roughly one-third of the 16 study species. Where species vulnerabilities are lower on lands managed by other agencies, it was recommended that the Army seek partnerships that can generate conservation success greater than what is likely to be gained by relying solely on withinthe-fenceline approaches.

\subsection{Climate change attributable to listed and at-risk species (Hohmann, Delaney, and Wall 2017)}

Hohmann, Delaney and Wall (2017) devised an approach based on a simple weighted sum of five factors that characterized an installation's (1) direct and indirect climate change exposure, (2) likely sensitivity to climate change exposure, (3) regional adaptive capacity, (4) potential vulnerability to listed and at-risk species, and (5) importance to the Army's overall training mission. Their approach was similar to the multiscale approach of Hohmann and Wall (2017), in that it utilized information about exposure, sensitivity and adaptive capacity; however, the climate change vulnerability of each species on an installation was not assessed separately, but rather collectively for all species within a regional landscape surrounding the installation. By evaluating fewer factors and eliminating emphasis on specific details about species' biology, which are often poorly known, they were able to streamline the climate change vulnerability assessment process.

Each of the five factors was summarized using one or more standardized subfactors that were also used by Hohmann and Wall (2017) or Wilhoit et al. (2016). For example, climate change exposure was characterized by changes in temperature and precipitation, and sea level (Table 3, A1, A2, and B1). Sensitivity was characterized by subfactors summarizing historical precipitation and temperature variability (Table 3, C2ai and C2bi). For adaptive capacity, subfactors related to anthropogenic barriers and occurrence of protected lands were evaluated (Table 3, B2B, and D4). Potential 
impacts of listed and at-risk species were characterized in a similar manner to Wilhoit et al. (2016) (see section 2.1), including information about the number and density of species on installations and the probability of listing of different taxonomic groups.

For the 43 CONUS Integrated Training Area Management (ITAM) installations evaluated by Hohmann, Delaney, and Wall (2017), the score of climate-change vulnerability ranged from 0.435 to 1.137. Comparing values of the exposure, sensitivity, and adaptive capacity factors, Hohmann, Delaney, and Wall (2017) were able to identify seven classes of installation vulnerability having different implications for prioritization and strategic planning (e.g., highly vulnerable versus potential adaptors and persisters). The values and rankings for the five installations evaluated by the two other approaches are shown in Table 2. 


\section{Results and Discussion}

Table 4 shows the scores for the three approaches described in Chapter 2 , as evaluated against the five SMART characteristics described in Table 1.

Table 4. Evaluation of SMART characteristics for the three climate change vulnerability assessment approaches. Scores are based on subject-matter expert opinion and represent low (1) to high (5) suitability.

\begin{tabular}{|l|c|c|c|}
\hline Characteristic & Wilhoit et al. (2016) & Hohmann and Wall (2017) & Hohmann, Delaney, and Wall (2017) \\
\hline Specific & 2 & 3 & 5 \\
\hline Measurable & 2 & 3 & 5 \\
\hline Attainable & 5 & 3 & 4 \\
\hline Realistic & 2 & 3 & 5 \\
\hline Timely & 5 & 2 & 4 \\
\hline Mean score & 3.5 & 2.8 & 4.6 \\
\hline
\end{tabular}

The first characteristic considered by the SMART process is whether a proposed MVA attribute is specific. The highest score (5) for this characteristic was assigned to the approach developed in Hohmann, Delaney, and Wall (2017). This approach has commonalities with the highly detailed, species-centric, multiscale assessment of Hohmann and Wall (2017), but it lacks some of the complexity that may make the latter potentially difficult to explain to individuals who lack training in biological science. Although clear and easily explained, the listed and at-risk species density approach of Wilhoit et al. (2016) was assigned the lowest score (2), because it does not specifically include information about climate change.

The second characteristic the SMART process evaluates is whether a potential MVA attribute is measurable. The highest score (5) for this characteristic was also assigned to the approach outlined in Hohmann, Delaney, and Wall (2017), which generates outputs that offer the greatest interpretation and potential for meaningful comparisons with other data. Values are standardized and exhibit variation among the five case-study installations included in all three approaches. Wilhoit et al. (2016) and Hohmann and Wall (2017) were assigned lower scores of 2 and 3, respectively (Table 4). The former offered little discriminatory information, as only two different values were estimated for the five case-study installations (Table 2). The latter offered greater discriminatory information, but two of the five installation case studies shared a common value. The ordinal outputs of the NS CCVI that are utilized in the multiscale approach of Hohmann and 
Wall (2017) can potentially constrain the variability of the vulnerability estimates of this approach when very few listed or at-risk species occur on an installation.

The third characteristic the SMART process evaluates is whether a proposed MVA attribute is attainable through reasonable measures under the expected conditions. The highest score (5) for this characteristic was assigned to the approach developed in Wilhoit et al. (2016) because of its simplicity and use of a limited number of variables. The data required to fulfill this attribute are readily available across all installations, allowing for wide-ranging comparisons of listed and at-risk wildlife species presence on military lands. Hohmann, Delaney, and Wall (2017) and Hohmann and Wall (2017) were assigned lower scores of four (4) and three (3), respectively (Table 4). The former approach uses a simple weighted sum of 5 factors to streamline the process for assessing climate change vulnerability, compared with the latter approach which uses 23 very detailed variables. By evaluating fewer factors and eliminating emphasis on species-specific biological information, which is poorly known, the approach of Hohmann, Delaney, and Wall (2017) is more easily attainable than that of Hohmann and Wall (2017).

The fourth characteristic the SMART process evaluates is whether a proposed MVA attribute is realistic (i.e. fits within the model and is cost-effective). Information relevant to all three of the approaches is constantly changing, and would probably need to be updated every couple of years, or even more frequently. There would be some cost associated with these updates. The highest score (5) for this characteristic was also assigned to the approach outlined in Hohmann, Delaney and Wall (2016) because it is sufficiently realistic, without being too complex, while also providing intermediate cost-effectiveness. Wilhoit et al. (2016) and Hohmann and Wall (2017) were assigned lower scores of two (2) and three (3), respectively (Table 4). The former would have the lowest cost because it only addresses two variables (i.e., presence of at-risk, candidate, and federally listed species and installation size), but would not have the same degree of realism for assessing the vulnerability of military installations to climate change as Hohmann and Wall (2017) and Hohmann, Delaney, and Wall (2017). The approach of Hohmann and Wall (2017) would be more costly than either of the other approaches. 
The last characteristic considered in the SMART process is whether a proposed MVA attribute is timely. Each of the three methods examined varies in the timeframe needed to provide results. The simplified nature of the approach of Wilhoit et al. (2015), which relies on only a couple of readily accessible variables (i.e., presence of at-risk, candidate, and federally listed species and installation size) and some simple straightforward calculations, provides the fastest output of all three methods (Table 4). If there is little lead time for incorporating species-specific information into the process, then this is the only timely approach. In contrast, the lowest score (2) was assigned to the multiscale vulnerability approach of (Hohmann and Wall 2016), which requires information on 23 factors that characterize individual species' sensitivity, exposure, and capacity to adapt to climate change, and as a consequence is very time consuming. Using this approach to generate an MVA attribute would need to be planned for in advance to allow enough time for the detailed analyses. As noted above, the approach developed in Hohmann, Delaney, and Wall (2017) has similarities to the multiscale approach of Hohmann and Wall (2017), but is less data intensive. Therefore, it should require an intermediate amount of time compared to the other two approaches.

The mean of the scores assigned to the five SMART characteristics was calculated as an aggregate summary score to aid assessment of the relative suitability of the three different approaches as an MVA attribute or as an external consideration (Table 4). The highest mean (4.6) was calculated for Hohmann, Delaney, and Wall (2017), the lowest mean (2.8) was calculated for Hohmann and Wall (2017), and an intermediate mean (3.5) was calculated for Wilhoit et al. (2016). Differences among these mean scores appear distinct enough to suggest that of the approach of Hohmann, Delaney and Wall (2016) has the most desirable characteristics for adoption as an MVA attribute or as an external consideration for informing future BRAC and restationing evaluations. 


\section{Conclusions and Recommendations}

\subsection{Conclusions}

The approach developed in Hohmann, Delaney, and Wall (2017) is likely suitable for consideration as an MVA attribute. However, it also could be incorporated as an environmental consideration if the military subjectmatter experts engaged during the MVA process do not wish to score it as a dedicated or multidimensional attribute.

\subsection{Recommendations}

The DoD has explicitly acknowledged, and has ongoing studies on, the potential impact of climate change and listed and at-risk species on missioncritical training and testing capabilities (DoD 2014). Based on the potential impacts in these areas, we recommend that the Department of the Army consider the approach developed in Hohmann, Delaney, and Wall (2017) in their MVA and deliberations during the next strategic stationing study. 


\section{Acronyms and Abbreviations}

$\begin{array}{ll}\text { Term } & \text { Definition } \\ \text { AET } & \text { actual evapotranspiration } \\ \text { BRAC } & \text { Base Realignment and Closure } \\ \text { CAA } & \text { Center for Army Analysis } \\ \text { CERL } & \text { Construction Engineering Research Laboratory } \\ \text { CONUS } & \text { Continental United States } \\ \text { DA } & \text { Department of the Army } \\ \text { ERDC } & \text { Engineer Research and Development Center } \\ \text { EPA } & \text { Environmental Protection Agency } \\ \text { ESA } & \text { Endangered Species Act } \\ \text { DoD } & \text { Department of Defense } \\ \text { INRMP } & \text { Integrated Natural Resources Management Plan } \\ \text { ITAM } & \text { Integrated Training Area Management } \\ \text { MVA } & \text { Military Value Analysis } \\ \text { NS CCVI } & \text { NatureServe Climate Change Vulnerability Index } \\ \text { PET } & \text { potential evapotranspiration } \\ \text { SMART } & \text { Specific, Measurable, Attainable, Realistic, and Timely } \\ \text { TES } & \text { Threatened and Endangered Species }\end{array}$




\section{References}

Bagne, K. E., M. M. Friggens, and D. M. Finch. 2011. A System for Assessing Vulnerability of Species (SAVS) to Climate Change. General Technical Report RMRS-GTR-257. Fort Collins, CO: U.S. Department of Agriculture, Forest Service, Rocky Mountain Research Station.

Byers, E., and S. Norris. 2011. Climate Change Vulnerability Assessment of Species of Concern in West Virginia. Project Report. Elkins, WV: West Virginia Division of Natural Resources, http://wvdnr.gov/publications/PDFFiles/ClimateChangeVulnerability.pdf

CNA Military Advisory Board. 2014. National Security and the Accelerating Risks of Climate Change. Arlington, VA: CNA, https:// www.cna.org/cna files/pdf/MAB 5-8-14.pdf, accessed 30 J anuary 2017.

Defense News. 6J une 2016. "Constituents to Congress: Let's Get BRAC Over With," https:// www.defensenews.com/ story/ defense/ commentary/2016/06/ 06/ constit uents-congress-lets-get-brac-over/ 85479424/, accessed 6 J une 2016.

Department of Defense (DoD). 2016. Report to Congress on Sustainable Ranges. Washington, DC: DoD, http://www.denix.osd.mil/sri/policy/reports/report-to-congress-onsustainable-ranges/2016-report-to-congress-on-sustainable-ranges/

Department of Defense (DoD). 2014. Office of the Deputy Under Secretary of Defense. Climate Change Adaptation Roadmap.

Department of Defense (DoD). 2005. Base Closure and Realignment Report. May 2004.

Gardali, T., N. E. Seavy, R. T. DiGaudio, and L. A. Comrack. 2012. A Climate Change Vulnerability Assessment of California's At-risk Birds. PLoS ONE 7(3): e29507. doi:10.1371/journal.pone.0029507

Government Accountability Office (GAO). 2005. Military Bases: Analysis of DoD’s 2005 Selection Process and Recommendations for Base Closure and Realignments. GAO-05-785. Washington, DC: GAO, http://www.gao.gov/products/GA0-05-785, p 13, accessed 30 J anuary 2017.

Hohmann, M. G., and W. A. Wall. J uly 2017. Multiscale Assessment of Listed and At-Risk Species' Climate Change Vulnerabilities. ERDC/ CERL TR-17-21. Champaign, IL: ERDC-CERL.

Hohmann, M. G., D. K. Delaney, and W. A. Wall. J uly 2017. Climate Change Vulnerability of Army Installations Attributable to Listed and At-Risk Species. ERDC/ CERL TR-17-22. Champaign, IL: ERDC-CERL.

Mawdsley, J ., and R. Lamb. 2013. Climate-Change Vulnerability Assessment for Priority Wildlife Species (of the Navajo Nation). The H. J ohn Heinz III Center for Science, Economics and the Environment, Washington, DC. 
NatureServe. 2014. Species at Risk on Department of Defense Lands: Updated Analysis, Report and Maps. DoD Legacy Project 14-772. Arlington, VA: NatureServe, http://www.dodnaturalresources.net/01_Species-Risk-Department-of-Defense-Lands-2014Updated-Analysis-Report-Maps-Report-Legacy-14-772.pdf, accessed 30 J anuary 2017.

Sperry, J . H., and T. J . Hayden. 2011. Use of a Climate Change Vulnerability Index for Assessing Species at Risk on Military Lands. ERDC/ CERL TR-11-29. Champaign, IL: ERDC-CERL, http://acwc.sdp.sirsi.net/client/search/asset/1006362

Sperry, J . H., W. A. Wall, and M. G. Hohmann. March 2016. Evaluation of 757 Species Under U.S. Endangered Species Act Review on U.S. Department of Defense Lands and their Potential Impact on Army Training. ERDC/ CERL TR-16-3. Champaign, IL: ERDC-CERL.

Stein B. A., C. Scott, and N. Benton. 2008. Federal lands and endangered species: The role of military and other Federal lands in sustaining biodiversity. BioScience 58(4)339- 347, http://www.nwf.org/ /media/PDFs/Global-

Warming/Reports/steinBioscience.pdf

Wilhoit, J. M., S. Tweddale, M. G. Hohmann, D. Delaney, M. E. Swearingen, and J . Westervelt. J anuary 2016. Effects of Climate Change, Urban Development, and Threatened and Endangered Species Management on Army Training Capabilities: Training Ranges. ERDC/ CERL TR-16-29. Champaign, IL: ERDCCERL.

Young, B. E., E. Byers, G. Hammerson, A. Frances, L. Oliver, and A. Treher. 2015. Guidelines for Using the NatureServe Climate Change Vulnerability Index. Release 3.0, Arlington VA: NatureServe, http://www.natureserve.org/biodiversityscience/publications/guidelines-using-natureserve-climate-change-vulnerability-index-0 


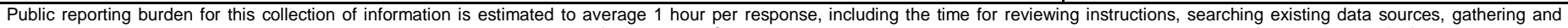

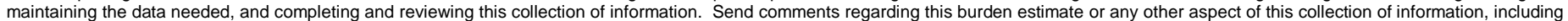

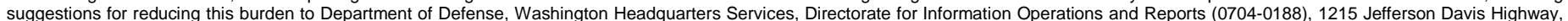

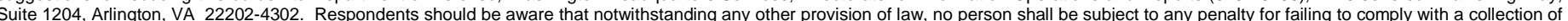
information if it does not display a currently valid OMB control number. PLEASE DO NOT RETURN YOUR FORM TO THE ABOVE ADDRESS.

1. REPORT DATE (DD-MM-YYYY) 1 2. REPORT TYPE

3. DATES COVERED (From - To)

July 2017

Final Technical Report

4. TITLE AND SUBTITLE

An Evaluation of Methods for Assessing Vulnerability of Army Installations to

Impacts of Climate Change on Listed and At-Risk Species

5a. CONTRACT NUMBER

6. AUTHOR(S)

Matthew G. Hohmann, David K. Delaney, and Michelle E. Swearingen

5b. GRANT NUMBER

5c. PROGRAM ELEMENT NUMBER

622720A896

5d. PROJECT NUMBER

2DC5L9

5e. TASK NUMBER

5f. WORK UNIT NUMBER

7. PERFORMING ORGANIZATION NAME(S) AND ADDRESS(ES)

U.S. Army Engineer Research and Development Center

Construction Engineering Research Laboratory

P.O. Box 9005

Champaign, IL 61826-9005

9. SPONSORING I MONITORING AGENCY NAME(S) AND ADDRESS(ES)

Office of Assistant Secretary of the Army for Acquisition, Logistics, and Technology

1400 Defense Pentagon

Washington DC 20301-1400

8. PERFORMING ORGANIZATION REPORT

NUMBER

ERDC/CERL TR-17-25

10. SPONSOR/MONITOR'S ACRONYM(S)

11. SPONSOR/MONITOR'S REPORT NUMBER(S)

\section{DISTRIBUTION / AVAILABILITY STATEMENT}

Approved for public release; distribution is unlimited.

\section{SUPPLEMENTARY NOTES}

\section{ABSTRACT}

Environmental factors have received only limited attention as part of past Base Realignment and Closure (BRAC) decision-making processes, and climate-change impacts have not yet been considered. During BRAC 2005, the Army considered listed and atrisk species as part of its environmental-criterion analysis. These species affect BRAC analyses given that their status can lead to restrictions on training land use, and that such restrictions are likely to increase under future rules addressing climate change. The objectives of this work were to identify prospective approaches for assessing the vulnerability of installations to climate-change impacts on listed and at-risk species, and to evaluate their suitability for informing BRAC-related evaluations. Three recently developed methods for assessing the vulnerability of Army installations to impacts of climate change on listed and at-risk species were evaluated using the SMART (Specific, Measurable, Attainable, Realistic, and Timely) decision analysis framework. Each method was rated against the SMART criteria and an aggregate score was provided. The assessment approach having the maximum aggregate score was recommended as likely suitable for informing future BRAC and restationing evaluations. It characterizes installation and regional climate change vulnerability by integrating multiple factors related to exposure, sensitivity, adaptive capacity, and number of listed and at-risk species.

\section{SUBJECT TERMS}

Military bases-United States; Endangered species; Climatic changes; Environmental impact analysis; Environmental management

16. SECURITY CLASSIFICATION OF:

\begin{tabular}{l|r}
\hline a. REPORT & b. ABSTRACT \\
Unclassified & Unclassified
\end{tabular}

17. LIMITATION OF ABSTRACT c. THIS PAGE

Unclassified
18. NUMBER OF PAGES

SAR
23 19a. NAME OF RESPONSIBLE PERSON 19b. TELEPHONE NUMBER (include area code) 